UDC: 633.39:582.663.2:631.562

DOI https://doi.org/10.15673/gpmf.v20i3.1844
${ }^{1}$ N. Valentiuk, Ph.D., Assistant Professor, E-mail: naval100@ukr.net ${ }^{2}$ G. Stankevych , Doctor of Technical Sciences, Professor, E-mail: georgii.stn@gmail.com https://orcid.org/0000-0002-0583-8174, ResearcherID: F-8557-2016

Scopus Author ID: 56184710800

${ }^{I}$ Department of Field and Vegetable Crops, Odessa State Agrarian University 13, Panteleymonovskaya Str., 65012, Odessa, Ukraine

${ }^{2}$ Department of grain storage technology, Odessa National Academy of Food Technologies, 112, Kanatna Str., 65039, Odessa, Ukraine

\title{
PECULIARITIES OF THE PROCESS OF PURIFICATION OF AMARANT GRAIN FROM IMPURITIES
}

\begin{abstract}
Proper and balanced nutrition is the key to a person's physical health, especially in the face of deteriorating environmental conditions and the effects of daily stress caused by the accelerated pace of life in recent years. In this regard, the attention of many researchers and entrepreneurs is focused on the development and implementation in mass production of foods that would fully meet human needs for protein, vitamins, micro-and micronutrients, etc. Recently, ingredients made from non-traditional vegetable raw materials have been used for the production of functional foods. Amaranth belongs to such vegetable raw materials. Amaranth culture has been known since ancient times, used by the ancient Aztecs. The main feature of this culture is the unique chemical composition, which causes an extremely wide range of its use, which is not limited to the food industry. In terms of amino acid composition, amaranth grain protein is close to the composition of an ideal protein. The presence of squalene in amaranth oil makes it possible to use it for the manufacture of medicines and cosmetics. However, despite the prospects for the use of amaranth, producers face difficulties with the characteristics of the grain of this crop. Small grain sizes require careful selection of mode parameters of technological equipment for post-harvest processing.

To substantiate the cleaning regimes, a study of the particle size distribution, physical-mechanical and aerodynamic properties of amaranth grain mass has been carried out.

Based on the research, it is established that despite the fact that some amaranth species like "shchyrytsya" have almost the same grain size and shape, the transgression coefficients calculated according to certain divisibility values can predict the possibility of separating a mixture of freshly harvested amaranth grain and its impurities, in particular from difficult to separate. It is proposed to use a set of sieves with round holes of the following sizes $(\mathrm{mm})$ to separate this mixture: $B 1-1.0 \ldots 1.1 ; B 2-1.0 \ldots 1.1 ; B 2-$ $1.0 \ldots 1.2 ; G 1-0.7 \ldots 0.9$; and elongated holes with dimensions $(\mathrm{mm}): B 1-(0.8 \ldots 1.0) \times 20, B 2-(0.5 \ldots 0.7) \times 20, B 1-(0.4 \ldots 0.6) \times 20$.

Key words: amaranth, grain, technology, postharvest processing of grain, cleaning of grain from impurities.
\end{abstract}

\section{Introduction}

The development of various technologies in recent years has significantly accelerated the pace of life in modern society. Some production technologies, despite the implementation of appropriate measures, are still capable of harming the environment. The stress caused by these phenomena, the deterioration of the environmental situation can lead to negative impacts and affect human health. That is why the attention of many scientists is focused on the development and implementation in production of functional products that can provide the human body with all the necessary substances. Nontraditional raw materials can be used as ingredients for such products. And such a plant as amaranth, due to the uniqueness of its chemical composition, is quite capable of use in this direction. It is important that all aboveground parts of this plant are edible, as they contain a large amount, compared to traditional cereals and oilseeds, of biologically active substances. This opens up an extremely wide range of opportunities for the use of amaranth in the food industry and in medicine, pharmacology, cosmetology, as well as in feed production and feeding of farm animals. Amaranth grain is especially valuable for further processing.

In addition to the above, an important feature of amaranth is that this culture is quite resistant to environmental conditions, it is also characterized by adaptability to growing in conditions of insufficient irrigation. Amaranth, according to many domestic and foreign researchers, is a cost-effective crop for growing and using. At present, a significant number of domestic varieties of amaranth have been bred, zoned and introduced into production in Ukraine: Ultra, Kharkiv, Aztec, Sam and Lera and many others.

But from harvesting to direct production of grain must go through a range of technological operations of post-harvest processing, which aims to prevent losses and preserve all its useful properties. Despite the large number of various grain cleaning and drying equipment on the market, producers face some difficulties in organizing and conducting post-harvest processing of amaranth grain. This is due to the fact that the physical and technological features of the grain of this crop require careful selection not only of the technological equipment, but also its operating parameters. Therefore, the development of a technological scheme for post-harvest processing of amaranth grain, taking into account its physical, technological and biochemical characteristics is an urgent issue.

\section{Literature review}

Despite the large number of studies on amaranth, most of them relate to the selection of new varieties, agricultural cultivation, isolation and study of certain substances from different aboveground parts of the plant, 
research of chemical composition, use of amaranth grain as raw material in the production of various foods [1- 8 , $13,14,18,24]$.

For example, many works by both national and foreign scientists are devoted to the study and study of the chemical composition and biochemical properties of various anatomical parts of amaranth. Among them are R. Saunders., R. Becker, (1984), whose studies have shown that the dependence of the species of amaranth on the chemical composition of the seeds varies greatly; and O. Konovalov, E. Ofitserov (1995), who found that amaranth pectins are able to combine with toxic metals and radioactive compounds and be excreted from the body as certain insoluble compounds. C. Kauffman and L. Weber (1990) proved that amaranth, like quinoa (Chenopodium quinoa), has the smallest, microcrystalline $0.8-2.5 \mu \mathrm{m}$ starch granules, which, in their opinion, is essential for both industrial applications and for use in food products. T. Chirkova (1999) found that amaranth seeds contain an average of $15-17 \%$ protein, $5-8 \%$ oil and $3.7-5.7 \%$ fiber, which is higher than in most cereals. : the protein content of corn is $10-12.6 \%$, fat $-4.6-6.7$, rice protein -8 , fat 1.1, wheat protein -9-14, fat - 1.1-3.4\%) [13, 18, 24].

The works of S. Lymanskaya, S. Mosyakin, K. Robertson, J. Abbot, G. Aynilian J. Pita and J. MartinezLaborde and others are devoted to the issue of species classification. A. Babych, E. Garmas, M. Girenko, V. Golovin, T. Goptsiy, A. Zheleznov, K. Chan, M. Coons, M. Sun, S. Desai, B. Joshi, A. were engaged in selection of new varieties. Mujica $[4,5]$.

S. Antonov, G. Babayev, V. Barylnyk, V. Belleva, Z. Kadyrova, S. Kohut, V. Kryuchkov, V. Moiseenko, E. Nikolaev, M. Altieri, M. Gorshunska were engaged in the development of cultivation technologies in different years, H. Hauptli [4].

The matters concerning processing and possibilities of use of amaranth in the food industry, medicine, fodder production and feeding of animals were researched by V. Gnoevyi, O. Dymchyn, Y. Duda, K. Iorgacheva, S. Kadoshnikov, L. Karnaushenko, O. Kozlovsky, O. Konovalov, N. Leontieva, O. Makeev, S. Pankova, Z. Tsaryk, I. Chernov, N. Shmalko, T. Yanyuk, W. Acar, W. Breene, R. Bressani, W. Broekaert [1-8].

L. Ovsyannikova, G. Stankevich, I. Chernousov, R. Abalone, A. Betschart, A. Cassinera, J. Roberts, E. Ronoh and others dealt directly with the issues of postharvest processing and storage of amaranth grain. [9-12, 15-17,19-21, 24-25].

So R. Abalone and others. studied the physical and technological properties, and T. Yanyuk studied the hygroscopic properties of amaranth grain of some varieties.

A.N. Calzetta Resio et al. [22] investigated the process of drying amaranth grain in a thin layer and presented a mathematical model and determined the coefficients that allow to predict this process with sufficient accuracy. Drying of amaranth grain with a humidity of $32.5 \%$ was performed at a temperature of the drying agent $+40 \ldots 70^{\circ} \mathrm{C}$. The grain moisture after drying was $5 \%$. Koltyugina O.V. a technological model of amaranth grain preparation for storage is proposed, which provides for acceptance, cleaning from impurities and drying of amaranth grain in mine grain dryers with a drying agent temperature of $+65 \ldots 90^{\circ} \mathrm{C}$. However, the authors did not take into account that the use of a drying agent with a temperature above $60^{\circ} \mathrm{C}$ can lead to a deterioration in the quality of amaranth grain.

CJTorres-Miño and co-authors [23] dried amaranth grain using microwave energy and concluded that microwave drying of amaranth seeds at $+40^{\circ} \mathrm{C}$ could be an alternative to convective hot air drying, as it would reduce the drying time by $22 \%$. and energy savings of $78 \%$ without affecting seed viability. Similar conclusions were obtained in the works of Stankevich G.M. [16-17] and Valentyuk N.A. [27]

Ronoh E.K. [26] simulated the process of drying a thin layer of amaranth grain in an open convective solar awning dryer. And although this method of drying is much cheaper, it can not be used for natural and climatic conditions of Ukraine, because the harvest of amaranth falls in the autumn, when high humidity can reach $100 \%$, there are clouds and rain.

Zhuravlev O.B. and Borodkina O.V. developed a mathematical model for drying amaranth seeds in an apparatus with a suspended-twisted layer, which allows to intensify the drying process and increase technical and economic indicators and will be useful in the design of modern grain dryers.

Shmalko S.O. and Smirnov SO [19] proposed a method of cleaning amaranth grain from impurities to prepare it for grinding into food flour. The method involves the separation of grain mass into components using a pneumatic classifier with a closed air cycle for aerodynamic properties, photo separation on a photo separator ORTIMA. The use of a photo separator at the same time with increasing efficiency significantly increases the cost of the cleaning process.

\section{Formulation of the problem}

Amaranth grain differs not only in its unique nutritional value, which must be preserved in the process of post-harvest processing, but also in the small size of the grains, which requires careful selection of technological equipment for its processing. For this purpose it is necessary to substantiate the modes of purification of freshly harvested amaranth grain from impurities.

To achieve this goal, a number of tasks were formulated:

- To study of particle size distribution, physicomechanical and aerodynamic properties of amaranth grain depending on its humidity;

- To predict the possibility of separation of the grain mixture using the transgression coefficient;

- To provide recommendations on the choice of sieves for cleaning amaranth grain on sieve and sieve-air separators.

\section{Materials and methods}

Amaranth grain of Ultra variety was selected for research. This variety is a type of domestic selection. The originator is Kharkiv National Agrarian University. V.V. Dokuchaeva. Variety of "Ultra" was listed in the Register of Plant Varieties of Ukraine in 1998, early ripening, grain.

Sampling was performed according to DSTU ISO 13690: 2003. Grain moisture was determined according 
to DSTU 29144: 2009 (ISO 711-85).

To substantiate the modes of grain cleaning by conventional methods were determined: the angle of natural slope according to GOST 28254-89, particle size distribution, bulk density (nature) (GOST 10840-64), weight of 1000 grains according to (DSTU 10842-89), and grain porosity.

Analysis of particle size characteristics of grains and impurities was performed using methods of mathematical statistics based on direct measurements of length, width and thickness of individual grains. After that, using certain statistical characteristics of the grains of the main crop and impurities, the mass fractions of the components using the known patterns of distribution of the signs of divisibility predicted the possibility of separation of the grain mixture.

To determine the speed of soaring amaranth grain used a laboratory air classifier (Fig. 1).

The installation consists of a transparent conical tube, a fan and a settling chamber. An iris diaphragm is installed to regulate the flow of air pumped through the installation. The change in air flow rate is controlled after the inlet manifold by a U-shaped manometer installed in the cross section of the pipe at a distance of one diameter from the manifold. The wall thickness of the transparent conical pipe is $3 \mathrm{~mm}$, the inner diameter is $48.5 \mathrm{~mm}$, the opening angle of the collector is $\alpha=52.7^{\circ}$.

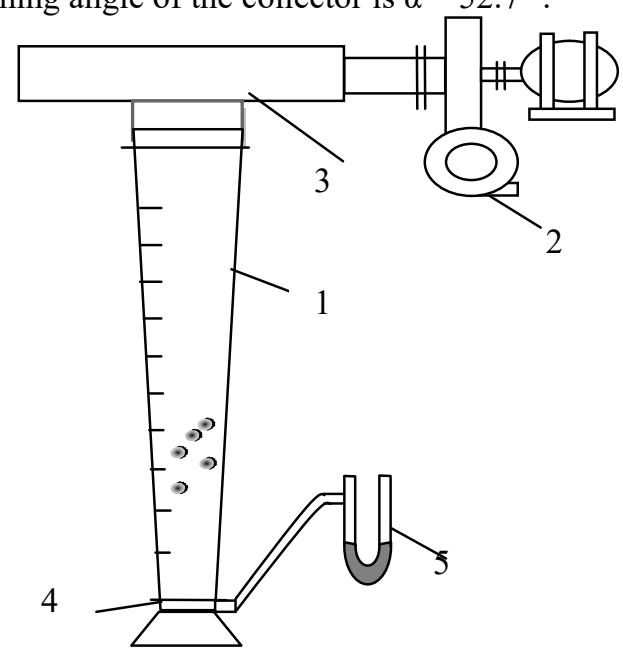

Fig. 1 - Installation for determining the speed of soaring grain:

1 - conical pipe; 2 -fan; 3 - sedimentation chamber, 4 - collector; 5 - U-shaped manometer.

At the inlet and outlet of the conical pipe mass air flow is the same, i.e.

where

$$
Q_{1}=Q_{2} \text { or } v_{1} F_{1}=v_{2} F_{2},
$$

$v_{2}=v_{1}\left(F_{1} / F_{2}\right)$.

To determine the speed of air flow in the section where the grain floats, enter the correction factor

$$
K=F_{1} / F_{2} \text {. }
$$

Since $F=\pi d^{2} / 4$, то $K=d_{1} / d_{2}$.

In the experimental setup, the diameter of the conical pipe in the inlet section $d_{1}=48.5 \mathrm{~mm}$. Since the pipe is a cone, the distance 1 from the inlet section of the pipe diameter will be

$$
d_{2}=d_{1}+\Delta d=d_{1}+2 l \sin \alpha,
$$

1 - is the height at which the proportion of the test sample fluctuates.

Given that in the installation at $l=100 \mathrm{~mm} \Delta d=$ $2,5 \mathrm{~mm}$, then $\sin \alpha=0,025$.

Then the correction factor $K$ will be equal to

$$
K=\frac{d_{1}^{2}}{\left(d_{1}+\Delta d\right)^{2}}=\frac{48.5^{2}}{(48.5+\Delta d)^{2}}=\frac{2325.25}{48.5+0.05}
$$

where $l$ is the height (number of divisions on the conical tube, $\mathrm{mm}$ ), near which the grains of the test specimen oscillate.

Determining the dynamic pressure in the inlet section

$$
H_{d}=g h, \mathrm{~Pa},
$$
nometer,

$h$ is the pressure determined by the U-shaped ma-

and, given that in this section $H_{\mathrm{d}}=H_{\text {st, }}$, you can calculate the air flow rate in the inlet section

$$
v=1.29 \sqrt{H_{\mathrm{d}}}, \mathrm{m} / \mathrm{s}
$$

and then the soaring speed of the test grain sample

$$
v_{\text {soar }}=V K, \mathrm{~m} / \mathrm{s}
$$

The experiments are repeated for 10 grains. The dependence of the search speed of the matters of the studied material on humidity is presented in a graph. If this graph gives the value of the polling rate, it can be concluded that they can be separated from the grain in the aspiration channels of air-sieve separators.

The information that the relationship between the fast life options and the parity coefficient $K_{P}$ is determined as follows:

$$
v_{\text {soar }}=\sqrt{\frac{g}{K_{\mathrm{p}}}},
$$

where $g$ is the acceleration of free fall, $\mathrm{m} / \mathrm{s}$.

\section{Results of the study and their discussion}

For the correct organization and conduct of the process of post-harvest processing of grain in connection with mechanization and automation, development and implementation of new methods of cleaning, drying grain, use of pneumatic transport, storage of grain in silos of modern elevators, metal bunkers, warehouses, taking into account physical, physical mechanical and aerodynamic characteristics of grain mass as an object of processing is of great importance. The correct calculation and correct use of these properties of the grain mass can significantly reduce losses by determining the optimal set of operations related to the production and use of grain.

Amaranth grain has a rounded lenticular shape with a diameter of 0.6 to $1.5 \mathrm{~mm}$. The seed coat consists of one layer, in the central part of the seed is smooth, the surface is slightly wrinkled in the area of the germ ring. The color of the grains can be from pale yellow to cream.

The linear sizes of separate grains of amaranth depending on humidity (tab. 1) can fluctuate within: length $1,20 \pm 0,30 \mathrm{~mm}$; width $1.02 \pm 0.28 \mathrm{~mm}$; thickness $0.95 \pm 0.35 \mathrm{~mm}$.

The physical and mechanical properties of the grain mass include such indicators as nature, angle of natural slope, weight of 1000 grains, duty cycle, dimen sional characteristics of individual grains, coefficients of friction and others (Table 1).

where $\alpha$ is the angle at the vertex of the cosine. 
Table 1 - Linear sizes of amaranth grains

$(\mathrm{n}=3, \mathrm{p} \geq 0,95)$

\begin{tabular}{|c|c|c|c|c|c|c|}
\hline \multirow{2}{*}{$\begin{array}{c}\text { Grain } \\
\text { moisture, } \%\end{array}$} & \multicolumn{2}{|c|}{ Length $(l), \mathrm{mm}$} & \multicolumn{2}{|c|}{ Width $(a), \mathrm{mm}$} & \multicolumn{2}{|c|}{ Thickness $(b), \mathrm{mm}$} \\
\hline & $\overline{\min }$ & $\overline{\max }$ & $\overline{\min }$ & max & $\overline{\min }$ & $\overline{\max }$ \\
\hline 9.2 & 1.02 & 1.20 & 0.74 & 1.10 & 0.73 & 1.00 \\
\hline 14.9 & 0.90 & 1.20 & 0.60 & 1.10 & 0.60 & 1.10 \\
\hline 19.3 & 0.99 & 1.50 & 0.90 & 1.30 & 0.80 & 1.30 \\
\hline
\end{tabular}

Studies of the geometric characteristics and physical and mechanical properties of the grain mass of amaranth (Table 1,2) allow us to conclude that each of the indicators in some way depends on the initial moisture content of the grain. Thus, with an increase in grain moisture from $9.9 \%$ to $18.9 \%$, there is an increase in the mass of 1000 grains by $2 \%$, the angle of natural slope $16 \%$. The value of nature decreases by $6 \%$. Also, an increase in humidity leads to an increase in the coefficients of friction at rest and in motion. These observations allow us to predict with sufficient accuracy changes in the specified properties of the grain mass of amaranth depending on its humidity, and, accordingly, to determine the complex and sequence of technological operations and select the optimal equipment modes.

With the known statistical characteristics of the grains of the main crop and impurities, taking into account the mass fractions of the components that make up the grain mass with the help of known patterns of distribution of signs of divisibility, it is possible to predict the possibility of separation of this mixture.

To determine the possibility of isolating amaranth, which is a difficult-to-separate impurity, assume that the whole grain mass consists of the main crop (amaranth grain - 98\%) and impurities (Amaranthus retroflexus $L$. - another species of "shchyrytsya" grain - 2\%) (Table 3). This suggests that almost all grains (99.7\%) of both the main crop (amaranth) and impurities (specie of amaranth called "shchyrytsya") are in the zone $x \pm 3 s$.

In this case, complete separation of the grain mixture will be possible provided:

$$
x_{1}+3 s<x_{2}-3 s \text {, }
$$

where $x_{1}, x_{2}$ - the average size of the main crop and impurities;

$s$ - standard deviations.

It is possible to estimate the divisibility of this grain mixture by determining the transgression coefficient $T$, which is the fraction of the area of mutual penetration (compatible for distribution) to the total area:

$$
T=\frac{m_{1} P_{1}+m_{2} P_{2}}{m_{1}+m_{2}}
$$

where $m_{1}, m_{2}$ - mass fractions of components 1 and 2 (amaranth and shchyrytsya);

$P_{1}, P_{2}$ - fractions of the area of mutual (compatible) overlap of the distribution of components 1 and 2 .

In the case of the normal distribution law $P_{1}$ and $P_{2}$ is determined by the table of values of the normalized Laplace function:

$$
\begin{aligned}
& P_{1}=0.5 \pm \Phi\left(t_{1}\right) ; \quad t_{1}=\left|\frac{x_{2 \text { min }}-x_{1 \text { aver }}}{s_{1}}\right| ; \\
& P_{2}=0.5 \pm \Phi\left(t_{2}\right) ; \quad t_{2}=\left|\frac{x_{2 \text { min }}-x_{2 \text { aver }}}{s_{2}}\right|,
\end{aligned}
$$

\begin{tabular}{|c|c|c|c|c|c|c|c|c|c|}
\hline \multirow{2}{*}{\multicolumn{2}{|c|}{ Test sample }} & \multirow{2}{*}{ 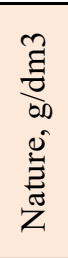 } & \multirow{2}{*}{ 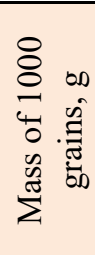 } & \multirow{2}{*}{ 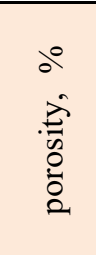 } & \multirow{2}{*}{ 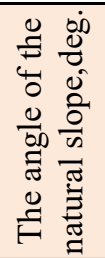 } & \multicolumn{3}{|c|}{$\begin{array}{c}\text { Coefficients of external friction } \\
\text { at rest: }\end{array}$} & \multirow{2}{*}{ 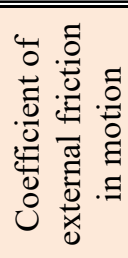 } \\
\hline & & & & & & plastic & steel & rubber & \\
\hline \multirow{3}{*}{$\begin{array}{c}\text { Grain } \\
\text { moisture, } \\
\%\end{array}$} & 9.9 & 762 & 0.687 & 40.10 & 25 & 0.314 & 0.309 & 0.363 & 0.287 \\
\hline & 14.5 & 7440 & 0.699 & 39.66 & 27 & 0.327 & 0.318 & 0.382 & 0.308 \\
\hline & 18.9 & 715 & 0.701 & 40.84 & 29 & 0.349 & 0.335 & 0.389 & 0.311 \\
\hline
\end{tabular}

Table 2 - Physico-mechanical properties of amaranth grain mass

\begin{tabular}{|c|c|c|c|}
\hline Components & Thickness, mm & Width, mm & Length, mm \\
\hline Amaranth & $0.5-1.3$ & $0.6-1.7$ & $0.7-2$ \\
\hline min & 0.50 & 0.60 & 0.70 \\
\hline max & 1.30 & 1.70 & 2.00 \\
\hline Average value & 0.90 & 1.15 & 1.35 \\
\hline The standard deviation & 0.13 & 0.18 & 0.22 \\
\hline Amaranth (other specie "shchyrytsya") & $0.4-1.1$ & $0.6-1.5$ & $0.5-1.7$ \\
\hline $\min$ & 0.40 & 0.60 & 0.50 \\
\hline$\overline{\max }$ & 1.10 & 1.50 & 1.70 \\
\hline Average value & 0.75 & 1.05 & 1.10 \\
\hline The standard deviation & 0.12 & 0.15 & 0.20 \\
\hline
\end{tabular}

Table 3 - Initial parameters of the grain mixture

$(n=3, p \geq 0,95)$ 
where $\Phi(t)$ is the value of the Laplace function;

$t_{1}, t_{2}$ - normalized values of the normal distribution;

$x_{1 \text { aver }}, x_{2 \text { aver }}$ - the average values of the sizes of components 1 and 2 :

$$
x_{2 \min }=x_{2 \text { aver }}-3_{S 2} ; \quad x_{1 \max }=x_{1 \text { aver }}+3_{S 1} \text {; }
$$

$s_{1}, s_{2}$ - standard deviations of the sizes of components 1 and 2 .

Substituting in the above formulas the corresponding values of the values we obtain the transgression coefficients:

$$
\begin{aligned}
& \text { by thickness: } \\
& T=\frac{98 \cdot 0.9463+2 \cdot 0.9773}{98+2}=0.95 ; \\
& \text { in width: } \\
& T=\frac{98 \cdot 0.9738+2 \cdot 0.9983}{98+2}=0.97 ; \\
& \text { in length: } \\
& T=\frac{98 \cdot 0.9441+2 \cdot 0.9793}{98+2}=0.94 .
\end{aligned}
$$

Calculations of transgression coefficients allow us to state that in the case when the thickness is a sign of divisibility - then only $5 \%$ of the cuticle can be removed; if the width is $3 \%$; if the length is $6 \%$. Therefore, the use of any one sign of divisibility is not able to achieve the desired effect. In this case, to separate the grain mixture, it will be advisable to use several signs of divisibility. Thus, we can conclude that by calculating the regression coefficient based on the established statistical indicators of grain size and impurities, it is possible to predict the efficiency of grain cleaning.

Aerodynamic properties of grain are characterized by such indicators as speed of soaring and soaring ratio. The results of studies of the aerodynamic properties of amaranth grain are given in table. 4 .

Table 4 - Experimental values of soaring speed and soaring coefficient of amaranth grain

$(\mathrm{n}=3, \mathrm{p} \geq 0.95)$

\begin{tabular}{||c||c||c||}
\hline $\begin{array}{c}\text { Grain } \\
\text { moisture, \% }\end{array}$ & $\begin{array}{c}\text { Soaring } \\
\text { speed, } \mathrm{m} / \mathrm{s}\end{array}$ & $\begin{array}{c}\text { Coefficient of } \\
\text { soaring, 1 / m }\end{array}$ \\
\hline \hline 9.5 & 3.28 & 0.91 \\
\hline \hline 12.1 & 3.32 & 0.89 \\
\hline \hline 14.3 & 3.38 & 0.86 \\
\hline \hline 16.8 & 3.45 & 0.82 \\
\hline \hline 19.5 & 3.51 & 0.79 \\
\hline
\end{tabular}

After the mathematical processing of the research results, it was found that the dependence of the soaring speed and soaring coefficient on the moisture content of amaranth grain is linear. The dependence of the hovering speed and sail coefficient on grain moisture is described by the following expressions:

$$
\begin{aligned}
& v_{\text {soar }}=3,043+0,024 w, \\
& K_{\mathrm{s}}=1,035-0,013 w .
\end{aligned}
$$

The results show that with increasing humidity of amaranth grain from $9.5 \%$ to $19.5 \%$, the soaring speed increases by $7 \%$, and the soaring coefficient decreases by $13 \%$.

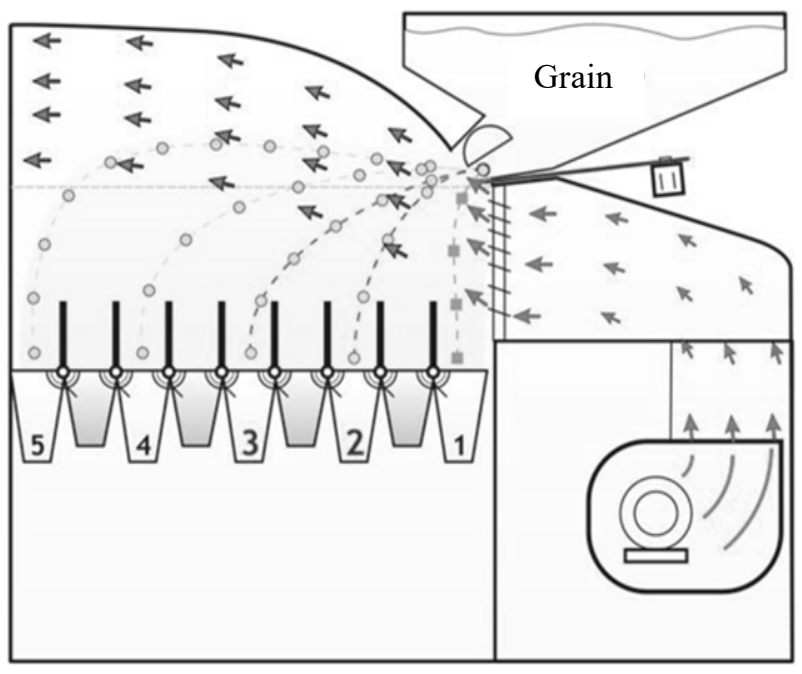

Fig. 2 - Technological scheme of aerodynamic separator: 1 - large impurities; 2, 3 -purified grain; 4, 5 - light impurities, thin and broken grain

\section{Approbation of research results}

The obtained research results will be useful in the organization and conduct of post-harvest processing of freshly harvested amaranth grain.

Quite small sizes of amaranth grains (0.6... 1.5 $\mathrm{mm}$ ) and, accordingly, low soaring speed (3.3.. 3.5 $\mathrm{m} / \mathrm{s}$ ), determine the feasibility of cleaning the grain mass from impurities on non-sieve (aerodynamic) separators type ISN (ИСН), ALMAZ (АЛМАЗ), SAD (САД), "TOR" («TOP») or on grain cleaning complexes (mobile ZAV (3AB) type SOK (COK), etc.). Aerodynamic separators allow, in addition to cleaning the grain from impurities, to divide it into several fractions. Productivity of separators like SAD (САД) makes from 4 to $150 \mathrm{t} / \mathrm{h}$. Therefore, they can be recommended for small farms as well as for elevators and handling complexes.

The principle of operation of the aerodynamic separator (Fig. 2) is the distribution by specific gravity using air flows of grain mass into fractions. The grain mass is fed into the hopper-feeder, then using the grain feed regulator it is fed to the roller, where it is pseudoliquefaction and alignment over the entire thickness of the separation chamber. In the separation chamber, the grain is separated and separated by specific gravity, which occurs due to the action of air flows, which are formed by a high-pressure fan prepared by a jet generator. After separation, the grain is divided into fractions and sent to the receiving bins or immediately packed in containers (bags).

The capture of dust, fine particles and other light impurities contained in the grain mass is designated to the cyclone built into the separator.

In addition, for cleaning the grain mass of amaranth, you can also use already existing in the industry screen air separators or grain cleaning stationary complexes ZAV (3AB). In this case, to clean amaranth from impurities, we can recommend the shape and size of the holes of the sieves are given in table. 5 
Table 5 - Recommendations for the selection of sieves for cleaning amaranth grain on sieve and sieveair separators

\begin{tabular}{|c|c|c|}
\hline $\begin{array}{c}\text { Placement of } \\
\text { sieves }\end{array}$ & $\begin{array}{l}\text { Desig- } \\
\text { nation of } \\
\text { sieves } \\
\end{array}$ & $\begin{array}{c}\text { The size of the } \\
\text { holes sieves, } \\
\text { mm }\end{array}$ \\
\hline \multirow{5}{*}{$\begin{array}{l}\text { Б1 } \\
\text { Б2 } \\
\text { В1 }\end{array}$} & Б1(B1) & $\square(0,8 \ldots 1,0) \times 20$ \\
\hline & Б2 (B2) & $\square(0,5 \ldots 0,7) \times 20$ \\
\hline & $\mathrm{B} 1(\mathrm{C} 1)$ & $\square(0,4 \ldots 0,6) \times 20$ \\
\hline & $\mathrm{B} 2(\mathrm{C} 2)$ & $\varnothing 1,2$ \\
\hline & $\Gamma 1(\mathrm{D} 1)$ & $\varnothing 0,9$ \\
\hline
\end{tabular}

\section{Notes:}

1) the sizes of holes of sieves can vary within the specified limits depending on the geometrical sizes of a party of amaranth grain which are specified at carrying out trial cleaning according to "Instructions № 9-5-82 on cleaning";

2) the air flow rate in the pneumatic channel of the separator is adjusted according to the size of the grain to prevent its removal into the waste impurities

\section{Conclusions:}

Determining the main geometric characteristics, physical-mechanical and aerodynamic properties of amaranth grain depending on its humidity will allow in the future with sufficient accuracy to model the post-harvest processing process and select the optimal operating parameters of the technological equipment used.
1. It is proved that an increase in the moisture content of amaranth grain from 9 to $19 \%$ leads to an increase in the geometric dimensions of an individual grain. As the moisture content of amaranth grains also increases, the mass of 1000 grains increases by $2 \%$, the angle of natural slope by $16 \%$, the coefficients of friction at rest and in motion, and the natural weight decreases by $6 \%$. The speed of soaring of amaranth grain is $3.28 \ldots$ $3.51 \mathrm{~m} / \mathrm{s}$, and the coefficient of soaring is $0.91 \ldots 0.79$, respectively. As the humidity increases, the soaring speed increases by $7 \%$ and the soaring coefficient decreases by $13 \%$, which must also be taken into account during active ventilation and drying of amaranth grain.

2. Based on the calculation of transgression coefficients, the possibility of predicting the separation of a mixture of freshly harvested amaranth grain and its impurities, in particular, difficult-to-separate amaranth, is shown. Despite the fact that there is some a close relative of amaranth called "shchyrytsya" and has almost the same size and shape of the grain, it can be removed from the grain mass.

3. The conducted researches allow giving recommendations on the choice of sieves for cleaning of amaranth grain on sieve and sieve-air separators. To isolate the main impurities, we can recommend a set of sieves with round holes of the following sizes $(\mathrm{mm})$ : $\mathrm{B}_{1}$ $1.0 \ldots 1.1 ; \mathrm{B}_{2}-1.0 \ldots 1.1 ; \mathrm{B}_{2}-1.0 \ldots 1.2 ; \mathrm{D}-0.7 \ldots 0.9$; and elongated holes with dimensions $(\mathrm{mm}): \mathrm{B}_{1}$ $(0.8 \ldots 1.0) \times 20, \mathrm{~B}_{2}-(0.5 \ldots 0.7) \times 20, \mathrm{C} 1-(0.4 \ldots 0.6) \times 20$

\section{REFERENCES}

1. Amarant - prodovol'stvennaya kul'tura (proiskhozhdeniye, sistematika, morfologiya, fiziologiya, introduktsiya, vozdelyvaniye, khimicheskiy sostav, sushka, khraneniye, pererabotka, primeneniye): monografiya / R.U. Uazhanova, YU.F. Roslyakov, I.M. Zharkova, N.A. Shmal'ko. - Krasnodar: Izd. FGBOU VO «KubGTU», 2016. - 348p.

2. Amarantove boroshno - perspektyvna kharchova dobavka u vyrobnytstvi morozyva / O.V. Hulak, H.YE. Polishchuk, H.P. Kalinina, T.I. Yanyuk // Produkty \& ynhredyenty. - 2007. no. 6. pp. 74-76.

3. Vysochina G.I. Amarant (amaranthus l): khimicheskiy sostav i perspektivy ispol'zovaniya (obzor) // Khimiya rastitel'nogo syr'ya. 2013. no. 2. pp. 5-14.

4. Hoptsiy T.I. Amarant: biolohiya vyroshchuvannya, perspektyvy vykorystannya, selektsiya: monohrafiya. Kharkiv: Khark. derzh. ahrar. Un-t. 1999. 273p.

5. Zheleznov A.V. Amarant - khleb, zrelishche i lekarstvo // Khimiya i zhizn'. 2005. no. 6. pp. 56-61

6. Zhuravel' N.V. Zernovoy amarant-perspektivnaya kul'tura / N.V. Zhuravel', V.V. Chumakova, V.V. Martirosyan // Dostizheniya nauki i tekhniki APK, 2012. no. 10. pp. 71-72.

7. Kadyrov S.V. i dr.Zernovoy amarant - perspektivnaya kul'tura TSCHR // Sb. nauch. trudov «Povysheniye urozhaynosti polevykh kul'tur». Voronezh: VGAU, 2004. pp. 47-49

8. Kazumyan A.K. Ispol'zovaniye amaranta v proizvodstve pishchevogo spirta i krepkikh napitkov // Vinodeliye $i$ vinogradstvo. 2004. no. 2. pp. 25-26.

9. Kol'tyugina, O.V. Tekhnologicheskaya model' podgotovki amaranta dlya khraneniya / O.V. Kol'tyugina, I.F. Kostikov // Polzunovskiy vestnik, 2012. no. 2/2. pp. 144-148.

10. Mikrovolnovyye tekhnologii v APK. Tuchnyy V.P., Kalinin L.G., Levchenko Ye.A., Kindruk N.D. // Khraneniye $i$ pererabotka zerna. 2002. no. 12. pp. 24.

11. Miroshnichenko L.A $i$ dr. Khraneniye zerna amaranta i produktov yego pererabotki // Khraneniye $i$ pererabotka sel'khozsyr'ya. 2006. no. 4. pp.20-21.

12. Ovsyannykova L. ta in. Pry $-5^{\circ} \mathrm{C}$ fermentatyvni protsesy $v$ dribnonasinnyevykh oliynykh kul'turakh spovil'nyuyut'sya // Zerno i khlib. 2009. no. 3. pp.33-34

13. Ofitserov Ye.N. Amarant - perspektivnoye syr'ye dlya farmatsevticheskoy promyshlennosti // Materialy dokladov 1-oy Rossiyskoy nauchno-prakticheskoy konferentsii "Aktual'nyye problemy innovatsiy s netraditsionnymi rastitel'nymi resursami i sozdaniya funktsional'nykh produktov". Khimiya i komp'yuternoye modelirovaniye. Butlerovskiye soobshcheniya. 2001, no. 5.

14. Roslyakov YU., Bochkova L., Shmal'ko K. Ispol'zovaniye amaranta v khlebopechenii // Khliboprodukti. 2004. no. 11. pp. 46-47.

15. Smirnov, S. Tekhnologiya ochistki zerna pered pomolom / S. Smirnov// Khleboprodukty. 2006. no. 2. pp. 50-52.

16. Stankevych G., Valentiuk N. Teoreticheskaya prorabotka sposobov sushki zerna amaranta // Materials of X International scientific and practical conference, "Prospects of world science". 2014. V.8. pp. 21-27. 
17. Stankevych G.M., Valentiuk N.O. Vplyv umov sushinnya na posivni yakosti nasinnya amarantu // Ahrarnyy visnyk Prychornomor"ya. Zb. nauk. prats', 2018. Vyp. 87. pp.43-50.

18. Chirkova T.V. Amarant-kul'tura XXI veka // SOZH, 1999, no. 10. pp. 22-27.

19. Shmal'ko N.A., Smirnov S.O. Sposob ochistki zerna amaranta ot primesey. Tekhnika i tekhnologiya pishchevykh proizvodstv. 2017. T. 46. no. 3 pp.114-120

20. Yanyuk, T. I. Hihroskopichni vlastyvosti amarantu / T. I. Yanyuk, N. V. Hryunval'd, K. YU. Radets'ka // Khranenye y pererabotka zerna. 2010. no. 2. pp. 34-35.

21. Abalone R., Cassinera A., Gastón A., Lara M.A. Some physical properties of amaranth seeds. Biosystems Engineering. 2004; 89(1): 109-117.

22. Calzetta Resio A.N., Aguerre R.J., Suarez C. Drying characteristics of amaranth grain // Jornal of Food Engeneering. 2004. № 65. p. 197-203

23. C.J.Torres-Miño, R.H.Maqueda, A.H. Moreno. Adaptation Strategies and Microwave Drying of Amaranth Species with a High Nutritional Value to the Ecuadorian Andean Region / Nutritional Value of Amaranth. Edited by Viduranga Y. Waisundara https://www.intechopen.com/books/nutritional-value-of-amaranth

24. Kauffman C.S. and L.E. Weber. 1990. Grain amaranth. p. 127-139. In: J. Janick and J.E. Simon (eds.), Advances in new crops. Timber Press, Portland, OR.

25. Roberts J.S., Tong C.H. Drying kinetics of hygroscopic porous materials under isothermal conditions and the of a first-order reaction kinetic model for predicting drying // Int. J. Food Prop. 2003. № 3. P. 335.

26. Ronoh E.K. Modeling Thin Layer Drying of Amaranth Seeds under Open Sun and Natural Convection Solar Tent Dryer. Agricultural Engineering International: the CIGR Ejournal. Manuscript 1420. Vol. XI. November, 2009 URL: http://www.cigrjournal. org/index.php/Ejounral/article/viewFile/1420/1276

27. Valentiuk N.A. Zadorozhnyj V.G., Chulak Yu.L., Chulak O.L.The influence of drying method on the chemical amaranth seed structure // Nauka i studia. 2015. №10(141). p. 24-33.

УДК: 633.39:582.663.2:631.562

${ }^{1}$ Н.О. Валентюк, канд. техн. наук, ассистент, E-mail: naval100@ukr.net

Кафедра польових і овочевих культур,

${ }^{2}$ Г.М. Станкевич, д-р техн. наук, професор, E-mail: georgii.stn@gmail.com Кафедра технології зберігання зерна

${ }^{1}$ Одеський державний аграрний університет, 13, вул. Пантелеймонівська, Одеса, 65000, Украӥна

${ }^{2}$ Одеська національна академія харчових технологій, вул. Канатна, 112, Одеса, 65039, Україна

\section{ОСОБЛИВОСТІ ПРОЦЕСУ ОЧИЩЕННЯ ЗЕРНА АМАРАНТУ ВІД ДОМШШОК}

\section{Анотація}

Правильне та збалансоване харчування людини є запорукою ї̈ фізичного здоров'я, особливо в умовах погіршення екологічної ситуації та дї щцоденних стресів викликаних протягом останніх років прискореним темпом життя. У зв'язку з чим увага багатьох дослідників та підприємиів спрямована на розробку і впровадження у масове виробництво харчових продуктів, які б иілком забезпечували потреби людини у білку, вітамінах, мікро- та мікроелементах та ін. Останнім часом для виготовлення продуктів харчування функціонального призначення залучаються інгредієнти виготовлені з нетрадиційної рослинної сировини. Саме до такої рослинної сировини відноситься амарант. Культура амарант відома з давніх часів, використовувалась щзе прадавніми ацтеками. Головною особливістю ияієї культури є унікальний хімічний склад, щзо обумовлює надзвичайно широкий спектр його використання, який не обмежується тільки харчової промисловістю. За амінокислотним складом білок зерна амаранту наближується до складу ідеального білку. Наявність в амарантовій олї сквалену дає можливість використовувати ї̈ для виготовлення лікарських засобів, косметичних засобів. Однак не зважаючи на перспективність використання амаранту, у виробників виникають складнощі, щзо пов'язані з особливостями зерна иієї культури. Дрібні розміри зерна вимагають ретельного підбору режимних параметрів технологічного обладнання для післязбиральної обробки.

Для обтрунтування режимів очищення проведено дослідження гранулометричного складу, фізикомеханічних та аеродинамічних властивостей зернової маси амаранту.

На основі проведених досліджень встановлено, щзо незважаючи на те, щзо амарант та щуириця мають майже однакові розміри та форму зерна, за допомогою розрахованих за певними ознаками подільності значень коефіиієнтів трансгресії можна прогнозувати можливість розділення суміші свіжозібраного зерна амаранту та його домішок, зокрема від важко відокремлюваної щчириці. Запропоновано для розділення даної суміші застосовувати набір решіт з круглими отворами таких розмірів (мм): Б1 - 1,0 ..1,1; Б2 - 1,0 ...1,1; В2 - 1,0 ... 1,2; Г1 - 0,7...0,9; та продовгуватими отворами з розмірами $(м м):$ Б1 - $(0,8 \ldots 1,0) \times 20, \quad$ Б2 - $(0,5 \ldots 0,7) \times 20, B 1-$ $(0,4 \ldots 0,6) \times 20$.

Ключові слова: амарант, зерно, технологія, післязбиральна обробка зерна, очищення зерна від домішок. 


\section{ЛІТЕРАТУРА}

1. Амарант - продовольственная культура (происхождение, систематика, морфология, физиология, интродукция, воздельвание, химический состав, сушка, хранение, переработка, применение): монография / Р.У. Уажанова, Ю.Ф. Росляков, И.М. Жаркова, Н.А. Шмалько. - Краснодар: Изд. ФГБОУ ВО «КубГТУ», 2016. $348 c$.

2. Амарантове борошно - перспективна харчова добавка у виробництві морозива / О.В. Гулак, Г.С. Полішук, Г.П. Калініна, Т.I. Янюк // Продукты \& ингредиенты. 2007. № 6. С. 74-76.

3. Высочина Г.И. Амарант (amaranthus l): химический состав и перспективы использования (обзор) // Химия растительного сырья. 2013. №2. С. 5-14.

4. Гопиій T.I. Амарант: біологія вирощування, перспективи використання, селекиія: монографія. Харків: Харк. держ. аграр. Ун-т. 1999. 273c.

5. Железнов А.В. Амарант - хлеб, зрелище и лекарство // Химия и жизнь. 2005. №6. С. 56-61

6. Журавель Н.В. Зерновой амарант - перспективная культура / Н.В. Журавель, В.В. Чумакова, В.В. Мартиросян // Достижения науки и техники АПК, 2012. № 10. С. 71-72.

7. Кадыров С.В. и др.Зерновой амарант - перспективная культура ЦЧР // Сб. науч. трудов «Повышение урожайности полевых культур». Воронеж: ВГАУ, 2004. С. 47-49

8. Казумян А.К. Использование амаранта в производстве пищевого спирта и крепких напитков // Виноделие и виноградство. 2004. № 2. С.25-26.

9. Кольтюгина, О.В. Технологическая модель подготовки амаранта для хранения / О.В. Кольтюгина, И.Ф. Костиков // Ползуновский вестник, 2012. № 2/2. С. 144-148.

10. Микроволновые технологии в АПК. Тучный В.П., Калинин Л.Г., Левченко Е.А., Киндрук Н.Д. // Хранение и переработка зерна. 2002. № 12. С. 24.

11. Мирошниченко Л.А и др. Хранение зерна амаранта и продуктов его переработки // Хранение и переработка сельхозсырья. 2006. № 4. С.20-21.

12. Овсянникова Л. та ін. При $-5^{\circ} \mathrm{C}$ ферментативні прочеси в дрібнонасіннєвих олійних культурах сповільнюються // Зерно і хліб. 2009. №3. С.33-34

13. Офицеров Е.Н. Амарант - перспективное сырье для фармачевтической промышленности // Материалы докладов 1-ой Российской научно-практической конференции "Актуальные проблемы инноваций с нетрадиционными растительными ресурсами и создания функциональных продуктов". Химия и компьютерное моделирование. Бутлеровские сообщения. 2001, №5.

14. Росляков Ю., Бочкова Л., Шмалько К. Использование амаранта в хлебопечении // Хлібопродукти. 2004 . №11. C. $46-47$.

15. Смирнов, С. Технология очистки зерна перед помолом / С. Смирнов // Хлебопродуктыл. 2006. № 2. С. 50-52.

16. Станкевич Г.Н., Валентюк Н.А. Теоретическая проработка способов сушки зерна амаранта // Materials of X International scientific and practical conference, "Prospects of world science". 2014. V.8. P. 21-27.

17. Станкевич Г.М., Валентюк Н.О. Вплив умов сушіння на посівні якості насіння амаранту // Аграрний вісник Причорномор'я. 3б. наук. пращь, 2018. Вип. 87. С.43-50.

18. Чиркова Т.В. Амарант - культура ХХІ века // СОЖ, 1999, № 10, с. $22-27$.

19. Шмалько Н.А., Смирнов С.О. Способ очистки зерна амаранта от примесей. Техника и технология пищевых производств. 2017. T. 46. № 3 c.114-120

20. Янюк, Т. І. Гігроскопічні властивості амаранту / Т. І. Янюк, Н. В. Грюнвальд, К. Ю. Радецька // Хранение и переработка зерна. - 2010. - № 2. - C. 34-35.

21. Abalone R, Cassinera A, Gastón A , Lara M.A. Some physical properties of amaranth seeds. Biosystems Engineering. 2004; 89(1): 109-117.

22. Calzetta Resio A.N., Aguerre R.J., Suarez C. Drying characteristics of amaranth grain // Jornal of Food Engeneering. 2004. № 65. p. 197-203

23. C.J.Torres-Miño, R.H.Maqueda, A.H. Moreno. Adaptation Strategies and Microwave Drying of Amaranth Species with a High Nutritional Value to the Ecuadorian Andean Region / Nutritional Value of Amaranth. Edited by Viduranga Y. Waisundara https://www.intechopen.com/books/nutritional-value-of-amaranth

24. Kauffman C.S. and L.E. Weber. 1990. Grain amaranth. p. 127-139. In. J. Janick and J.E. Simon (eds.), Advances in new crops. Timber Press, Portland, OR.

25. Roberts J.S., Tong C.H. Drying kinetics of hygroscopic porous materials under isothermal conditions and the of a first-order reaction kinetic model for predicting drying // Int. J. Food Prop. 2003. № 3. P. 335.

26. Ronoh E.K. Modeling Thin Layer Drying of Amaranth Seeds under Open Sun and Natural Convection Solar Tent Dryer. Agricultural Engineering International: the CIGR Ejournal. Manuscript 1420. Vol. XI. November, 2009 URL: http://www.cigrjournal. org/index.php/Ejounral/ article/viewFile/1420/1276

27. Valentyuk N.A. Zadorozhnyj V.G., Chulak Yu.L., Chulak O.L.The influence of drying method on the chemical amaranth seed structure // Nauka i studia. 2015. №10(141). p. 24-33.

\section{Received 09.06.2020 \\ Reviewed 07.07.2020}

\section{Revised 03.08.2020 \\ Approved 28.08.2020}

\section{Cite as Vancouver Citation Style}

Valentiuk N., Stankevych G. Peculiarities of the process of purification of amarant grain from impurities. Grain Products and Mixed Fodder's, 2020; 20 (3, 79): 10-19. DOI https://doi.org/10.15673/gpmf.v20i3.1844

\section{Cite as State Standard of Ukraine 8302:2015}

Peculiarities of the process of purification of amarant grain from impurities / Valentiuk N. et al. // Grain Products and Mixed Fodder's. 2020. Vol. 20, Issue 3 (79). P. 10-19. DOI https://doi.org/10.15673/gpmf.v20i3.1844

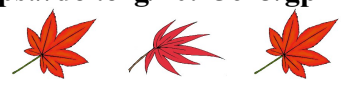

